\title{
The Ulli Beier Archives at the Centre for Black Culture and International Understanding (CBCIU), Nigeria, and a Summary of Holdings
}

\author{
RAHEEM Oluwafunminiyi
}

\begin{abstract}
The Centre for Black Culture and International Understanding (CBCIU) was established on 7 January 2009. Located behind the Osun State Secretariat, southwest Nigeria, the CBCIU prides itself on being the inheritor of the archival estate of Ulli Beier, the late German connoisseur and African culture enthusiast. Housed in its Archive and Documentation Room/Unit, this repository contains very rich archival materials that include over 700 photographs with carefully preserved negatives and slides all dating back to the 1950s, 1960s and early 1970s, and thousands of works of literature published between 1921 and the 2000s on virtually all aspects of Yoruba art, culture, philosophy and intellectual history. Based on fieldwork conducted at the CBCIU in 2018 and 2019, this study embarks on three mutually-connected transactions. First, it examines Ulli Beier's 'cultural border-crossings' into Yorubaland, particularly in Osogbo, southwest Nigeria, where his diverse cultural interactions facilitated the revival of a diminishing culture. Second, the study discusses the genesis of the CBCIU dating back to Ulli Beier's emergence in Nigeria in 1950. Third, it analyses what it means for the CBCIU to inherit an invaluable material legacy. This is done by giving an account of the inventories and a summary of the holdings in the Archives. While the Archive forms the very nucleus of what the CBCIU stands for, I argue that this agency serves as a worthy inheritor of a material legacy that continually seeks cultural relevance and perpetuity.
\end{abstract}

\section{INTRODUCTION}

The Centre for Black Culture and International Understanding (CBCIU), Osun State, southwest Nigeria, was established on 7 January 2009. It is reputed for holding rich archival materials dating back to the early 1950s inherited from Ulli Beier (1922-2011), the late German connoisseur and African culture enthusiast. The Archives contain virtually all aspects of African art, culture, philosophy and intellectual history, documented in literary and pictorial forms. The genesis of the CBCIU can be traced to Ulli Beier's formative years in the old Western Nigeria, particularly from 1951 to 1966 and later between 1971 and 1974. On arrival in colonial Nigeria, Ulli Beier was fascinated by ancient Yoruba culture and its powerful agencies but sadly worried by the threats posed by new religious movements, Westernisation and colonial rule. He therefore channelled his energy towards the preservation of countless examples of tangible and intangible culture of the local people that were mostly considered anachronistic. As such, he had the singular

RAHEEM Oluwafunminiyi is a Nigerian-based researcher. He specialises in social history, Yoruba cultural history and contemporary popular culture. His publications have appeared in book chapters and in journals such as African Notes and Yoruba Studies Review. Email: creativitysells@gmail.com 
honour of being trusted by the diverse cultural agencies with even the smallest of details handed down from their forebears. This, nevertheless, did not appear simple at first. Ulli Beier presented himself for initiation into the local powerful cults, facilitating the transfer of the categories of powers and knowledge inherited by these agencies to him. He was introduced and exposed to the mundane and celestial worlds of the Yoruba and was fully immersed in virtually all aspects of Yoruba life from the kingship institution, ritual performances and traditional festivals to orisa (deity) tradition and worship, poetry, local priests and everyday ordinary peoples. Being a complete insider, he was able to build lifelong relationships with Yoruba society and people which later spurred a collage of wellresearched and incisive literary and artistic productions that have stood the test of time. Considering his life work completed, Ulli Beier contemplated returning all the things he had inherited - that is, the Yoruba material culture (visual and non-visual) spanning about three decades - to the very site where they had been acquired. It is here that the CBCIU plays a very crucial role. However, Ulli Beier's pioneering efforts in African literary documentation and the extent to which he proceeded in charting a new course for Yoruba cultural history are worth exploring.

So also are discussions on his engagements with local agencies which together sustained the preservation of tangible and intangible cultural and traditional categories. As such, the study focuses briefly on Ulli Beier's travel itinerary in such Yoruba towns as Ede and Osogbo in particular (both in Western Nigeria). The Archives inherited from Ulli Beier which form the very nucleus of the CBCIU are critically examined. I argue that the CBCIU serves as a worthy inheritor of a material legacy that continually seeks cultural relevance and perpetuity.

\section{ULLI BEIER: ENGENDERING THE PRESERVATION OF A VANISHING CULTURE}

Ulli Beier's arrival in Nigeria on 1 October $1950^{1}$ coincided with the period of political ebullience in the country, particularly in the old Western Region. The Egbe Omo Oduduwa formed in London in 1945 by a group of young Western-educated men had become one of the new political parties in Nigeria. ${ }^{2}$ As expected, they had positioned themselves as representatives of the people and as the new elites in the country; their concerns were hinged on how to modernise and 'civilise' further their respective societies through Western attitudes and behaviours. Ulli Beier was unpleasantly surprised at the ardent admiration the emergent educated elites had for Westernisation while at the same time showing less concern for local traditions and cultures. ${ }^{3}$ Interestingly, a Yoruba cultural reawakening had begun around the early decades of the twentieth century and it was believed that the Egbe Omo Oduduwa, which surprisingly had started out as a cultural ensemble, would push forward this ideal, but the group appeared to be interested in other pursuits. It was this rather grave situation that fired Ulli Beier's enthusiasm to further the cultural rebirth, which had started decades ago, and amplify what he believed to be a new cultural understanding in Nigeria. Not long after, Ulli Beier found what one account regarded as his own edification, education and illumination about the Yoruba people as a whole. ${ }^{4}$

Ulli Beier moved to Ede in 1951, a town east of Ibadan where his ambition for spiritual and cultural knowledge was finally moulded. His three-year sojourn in the town and the close

\footnotetext{
${ }^{1}$ Ulli Beier's early life in Germany (1922-33), Palestine (1933-40) and London (1948-50) is well documented and does not need revisiting here. See Wole Ogundele, 'Rereading Beier', African Quarterly on the Arts, Vol. 2, No. 3, 1998, pp. 61-65; Rowland Abiodun, 'The Elephant Lies Down Like a Hill: Tribute to Ulli Beier 1922-2011', African Arts, Vol. 44, No. 4, 2011, pp. 4-7.

2 On the Egbe, see Samuel O. Arifalo, Egbe Omo Oduduwa: A Study in Ethnic and Cultural Nationalism (1945-1965), Akure: Stebak Books, 2001.

${ }^{3}$ Ulli Beier, 'The Attitude of the Educated African to his Traditional Art', The Phylon Quarterly, Vol. 18 , No. 2, 1957, pp. 162-65.

4 'Story of Ulli Beier', being an excerpt from a speech by Professor Wole Ogundele. http://www. centreforblackculture.org/content/story-of-ulli-beier.php, accessed 22 March 2019.
} 
friendship struck with the king, Oba Timi John Adetoyese Laoye I (1946-75) not only shaped and guided all his future relationships and actions, but also channelled his path to other traditional institutions and provided opportunities for him to integrate effectively into Yoruba cultural structure and social institutions. This, however, could not have been fully accomplished without a proper initiation into the $O g b o n i^{5}$ cult. $^{6}$ By virtue of being a devotee of this powerful traditional agency, he was in a vantage position to interact with priests, priestesses, healers, traditional rulers and devotees of several Yoruba religious cults for a deeper grasp of the categories that embody the macrocosmic world of the Yoruba. ${ }^{7}$

Partly as a responsibility to project Yoruba culture and partly to deflate what he termed the 'nimbus of viciousness'8 among the educated class for their heritage, Ulli Beier founded Odu, the Fournal of Yoruba Studies in 1954. He desired a platform, however, that could appeal to a much larger audience by featuring diverse themes from fiction, art, poetry and commentary contributed by, among others, Afro-American writers ${ }^{9}$ and young Nigerians, and also articles and photographs that connected with the diverse aspects of the past. ${ }^{10}$ Ulli Beier saw the importance of traditional art and literature in Africa, and felt a genuine desire to document them for posterity. It was here that Black Orpheus: A fournal of African and African American Literature was conceived in 1957. ${ }^{11}$ Through Black Orpheus, a term originally coined by Jean-Paul Sartre in a famous 1948 essay, Ulli Beier translated some of the works of renowned poets and writers such as Léopold Sédar Senghor, Aimé Césaire and Mallam Hampâté Bâ, among others, from French into English. This worthy dream soon sparked a literary flowering in Nigeria and across Anglophone West Africa.

Several extant works have been written on Black Orpheus ${ }^{12}$ whose abiding philosophy drove its passionate existence even after its editorship was given up by Ulli Beier to others from the 1960 s onwards. The magazine, however, emerged as an early response, or, to put it more distinctly, as a critical intervention by Ulli Beier to put together in documentary forms the story of local peoples, given the pressures of new religious beliefs, colonial education and other eroding phenomena. Black Orpheus was not only regarded as 'a powerful catalyst for artistic awakening throughout West Africa', ${ }^{13}$ it set the pace for an in-depth, incisive and critical exposure and also desirous documentation of past human transactions and everyday socio-cultural interactions.

In 1958, Ulli Beier moved to Osogbo. Here, he developed a handful of multi-layered and multifaceted relationships with outcomes that would later define the cultural landscapes of post-independent Nigeria via a number of artistic and cultural agencies. Through the highly

\footnotetext{
${ }^{5}$ The Ogboni was a very powerful political institution and secret society in Yorubaland founded originally to worship the earth. On the Ogboni, see Peter Morton-Williams, 'The Yoruba Ogboni Cult in Oyo', Africa: Fournal of the International African Institute, Vol. 30, No. 4, 1960, pp. 362-74; Kolawole Komolafe, African Traditional Religion: Understanding Ogboni Fraternity, Lagos: Ifa-Orunmila Organisation, 1995.

6 Text of the speech delivered by Professor Siyan Oyeweso, Executive Director, CBCIU at the National Colloquium on the Reflections on the Enduring Legacies of Duro Ladipo (1931-1978), held at the Ulli Beier Hall, CBCIU, 13 March 2018.

7 Wole Ogundele, Omoluabi: Ulli Beier, Yoruba Society and Culture, Bayreuth African Studies, 2003, p. 71 .

8 Beier, 'The Attitude of the Educated African' p. 164.

9 See Ulli Beier and Janheinz Jahn, 'Editorial', Black Orpheus: A fournal of African and Afro-American Literature, No. 1, 1957.

${ }^{10}$ John Pemberton III, 'Ulli Beier and the Oshogbo Artists of Nigeria', African Studies Review, Vol. 45, No. 1, 2002, p. 115-16.

11 Abiola Irele, 'A Defence of Negritude', Transition, No. 13, 1964, pp. 9-11.

12 See, for instance, Bernth Lindfors, 'A Decade of Black Orpheus', Books Abroad, Vol. 42, No. 4, 1968, pp. 509-16; Peter Benson, "Border Operators": Black Orpheus and the Genesis of Modern African Art and Literature', Research in African Literatures, Vol. 14, No. 4, 1983, pp. 431-73; Peter Benson, Black Orpheus, Transition and Modern Cultural Awakening Africa, Los Angeles: University of California Press, 1986.

${ }^{13}$ Kate Tuttle, 'Black Orpheus: Literary Magazine Based in Nigeria', in Anthony Appiah and Henry Louis Gates, Jr. (eds), Encyclopedia of Africa, Oxford: Oxford University Press, 2010, p. 189.
} 
influential dramatist and playwright, Duro Ladipo, who had been inspired by the activities of the original Mbari Club in Ibadan, Ulli Beier helped to establish Mbari Mbayo in Osogbo which opened on 21 March 1962. It became a fertile ground for all kinds of cultural and artistic activities such as batik exhibitions, drama productions, traditional dance performance and performances by poets and musicians. ${ }^{14}$ It was at Mbari Osogbo that the second experimental art workshop was held where young talented artists were discovered and who soon became the kernel of what is popularly referred to today as the Osogbo Art Movement. ${ }^{15}$

In December 1966 feeling he had nothing more to contribute, Ulli Beier left Nigeria for a new adventure in Papua New Guinea. An eleven-year cultural and artistic sojourn came to an end, albeit not for long. ${ }^{16}$ Not only did he find illumination from the insights he had gained from custodians of Yoruba culture, he reciprocated this as a form of obligation to diffuse what was at the time a 'passing grandeur' across the world. It is to Ulli Beier's ingenuity that the 1950s and 1960s are often spoken of as a momentous period of great cultural re-awakening in Yorubaland - an enduring legacy that lives in perpetuity. ${ }^{17}$

\section{THE CBCIU: A BRIEF HISTORY}

The CBCIU, affiliated with the UNESCO Category $2^{18}$ Institute for African Culture and International Understanding based in Abeokuta, Ogun State, southwest Nigeria, was established as a hub for the preservation and promotion of African culture and tradition. Within a decade of its formation, the CBCIU has expressed these commitments in several ways through a number of activities and programmes on African culture, cultural expressions and other global cultural collaborations that sit well with its objectives. Officially commissioned in January 2009 by Koichuro Matsuura, the then Director General of UNESCO, the CBCIU opened for business in March of the same year. Typical of cultural constructs of this nature, the genesis of the CBCIU is said to date back to the 1950s, a period noted earlier when Ulli Beier had spent quality time in several Yoruba towns. At Okuku, which he visited in the late 1950s, for instance, Ulli Beier often spoke of his close friendship with the then traditional ruler, Moses Oyinlola (1934-60), which decades later inspired several writings and publications on not only the town, its culture and tradition but also on the king. ${ }^{19}$

In 2004, Ulli Beier and his wife Georgina were invited to Nigeria by the children of Oba Oyinlola. A biography was about to be compiled and given Ulli Beier's relationship with Oba Oyinlola, it became necessary to invite him in order to shed further light on the late monarch. ${ }^{20}$ Prince Olagunsoye Oyinlola, one of the children of the late monarch had met with the Beiers on this visit and had quite fruitful discussions, a part of which was to secure a final resting place for Ulli Beier's entire Archives in Nigeria. For inexplicable reasons, this

\footnotetext{
${ }^{14}$ Muraina Oyelami, 'Mbari Mbayo and the Oshogbo Artists', African Arts, Vol. 15, No. 2, 1982, p. 85 .

${ }^{15}$ Margaret Mwantok, 'Celebrating the Golden Years of Osogbo School of Art', Guardian [Nigeria], 15 January 2017.

${ }^{16}$ Ulli Beier returned to Nigeria in 1970 to take up the position of Director, Institute of African Studies, University of Ife (now Obafemi Awolowo University, Ile-Ife, Nigeria).

${ }^{17}$ Eckhard Breitinger, 'In Memory of Ulli Beier', African Studies Bulletin, No. 73, 2011, p. 69.

18 The significance of the Category 2 Institute could be seen in terms of collaborative partnerships with UNESCO which in many ways contributes to the latter's priority areas, extending the network of its programmes and achieving its strategic programme objectives for the interest of Member States. Within the cultural sphere, they aid in the protection, dissemination and protection of collective heritage and cultural expressions. See, for more details, Category 2 Institutes and Centres under the Auspices of UNESCO, https://en.unesco.org/partnerships/culture/Category-2-Centres, accessed 19 September 2019.

${ }^{19}$ For instance, Ulli Beier, Yoruba Beaded Crowns: Sacred Regalia of the Olokuku of Okuku, London: Ethnographica, 1982.

${ }^{20}$ Olagunsoye Oyinlola, 'Forward', in Wole Ogundele (ed.), Gone to foin Obatala: Tributes on Ulli Beier, Osogbo: Centre for Black Culture and International Understanding, 2012, p. i.
} 
discussion did not actually bear fruit until 2006, when the Nigerian Federal Government approached Ulli Beier for the acquisition of these rare but invaluable collections. It must be noted that Ulli Beier had for quite some time considered retirement and desired that all his private art collections and archival materials he had gathered and inherited in the 1950s and 1966 across Yorubaland should be transferred from his base in Sydney, Australia, and housed in Nigeria, with Osogbo his preferred location. Osogbo held a special place for Ulli Beier - he and both his first wife, Susanne Wenger, and later Georgina, had spent their most culturally fruitful years there between 1958 and 1966. ${ }^{21}$ Susanne Wenger would remain in Osogbo until her death in 2009. As for Georgina (1938-), she had moved from Zaria in northern Nigeria to Osogbo in 1963, and in the following year, married Ulli Beier. At Osogbo, she immersed herself in the local art setting, holding annual artistic workshops at the Mbari Mbayo Club, Osogbo, which would later produce an array of international artists. Georgina was concerned with authenticity that drew upon individual talent. She attached importance to techniques and media whose output would be influenced by the immediate cultural environment of the workshop participants. ${ }^{22}$ Apart from this, Georgina was very much active in the theatre company of Duro Ladipo, where she was involved in designing stage costumes, drawings and paintings, and making beautiful backdrops. She left with Ulli Beier in 1966 and continued these artistic engagements in other countries. ${ }^{23}$

For Ulli Beier, the government's proposal appeared attractive but he was of the view that all his life works should be domiciled in Osogbo, with Prince Oyinlola, himself a culture enthusiast, as the life Chairman of the Board of Trustees of the yet-to-be-instituted Centre that would accommodate these collections. To guarantee the safety and integrity of these rare materials, Ulli Beier involved UNESCO as a potential partner. Following a feasibility report submitted to UNESCO by a home team, two different teams were sent by UNESCO between 2007 and mid-2008 for an on-the-spot assessment and recommendation to the Executive Board. By the end of 2008, the home team visited UNESCO in Paris to make a case for the CBCIU as a Category 2 Institute affiliate to the African Forum of the Executive Board which formally presented the case and at the same time granted its wish. ${ }^{24}$ By this gesture, the CBCIU was born and emerged ultimately as the first UNESCO cultural sector Category 2 Institute in Africa.

Following its establishment, a Board of Trustees (BoT) was constituted. This was made up of eminent personalities among whom are two surviving members of the Osogbo Art School, two academic professors, an experienced bureaucrat who is the Secretary of the BoT, a representative of the Nigerian Federal Ministry of Culture, and a representative of the UNESCO regional office in Abuja, Nigeria. ${ }^{25}$ Prince Oyinlola serves as Chairman of the Board. Wole Ogundele (now late), a distinguished Professor of English Literature and culture expert who had worked closely in the past with Ulli Beier, was appointed pioneer Executive Director of the CBCIU. 'With an intimate knowledge of the vision of the Centre', Omolewa notes, Ogundele brought his expertise to bear and through him 'appropriate programmes were mounted by the Centre involving the local populace as well as the international partners' ${ }^{26}$ Ogundele's untimely death in October 2014 marked the end of the personal expectations he had envisaged for the CBCIU. ${ }^{27} \mathrm{He}$ has since been replaced by two

21 Ulli Beier, Thirty Years of Osogbo Art, Bayreuth: Iwalewa, 1991.

${ }^{22}$ Katharina Greven, Lena Naumann, Siegrun Salmanian and Nadine Siegert, 'Collectivize (Re) sources: The Photographic Estate of Ulli Beier’, Critical Interventions, Vol. 12, No. 2, 2019, p. 143.

${ }^{23}$ For more, see Georgina Beier (ed.), Georgina Beier, Nürnberg: Verlag für moderne Kunst, 2001.

${ }^{24}$ Michael Omolewa, 'Historical Antecedents of the Centre for Black Culture and International Understanding, Osogbo', being the text of a speech on the tenth anniversary celebration of the Centre for Black Culture and International Understanding (CBCIU), Osogbo, held at the Ulli Beier Hall, CBCIU, 14 January 2019.

${ }^{25}$ Board of Trustees, http://www.centreforblackculture.org/board-of-trustees/index.php, accessed 22 March 2019.

${ }^{26}$ Omolewa, 'Historical Antecedents'.

27 Some of Professor Ogundele's legacies include: the organisation of the First Global Conference of Black Nationalities (23-27 August 2010); the Conference on Poetry and Performance in Indigenous 
consecutive Executive Directors, both of whom have sustained the tempo and surpassed Ogundele's 'personal expectations' vis-à-vis the objectives of the CBCIU.

\section{INHERITING AN INVALUABLE MATERIAL LEGACY}

What does it mean for the CBCIU to inherit a material legacy as that of the Ulli Beier Archives? The CBCIU is renowned for its rich Archives dating back to the 1950s, 1960s and early 1970 s - all inherited from Ulli Beier whose cultural transactions in the country produced vast amounts of tangible pictorial memories and invaluable materials. The CBCIU, it appears today, has inherited the philosophical, cultural and historical legacies of the Yoruba, rarely found in such large repositories across the world. This explains why the CBCIU is culturally strategic and important in the sense that it is the only agency that keeps alive and still holds the material remains of the Yoruba cultural history of a particular historical material time, most of which are physically inaccessible today. The materials in the Archives are a reminder of Ulli Beier's desperate last-gasp effort to secure for posterity the 'vanishing' universality of the Yoruba.

Siting the CBCIU in the heart of Osogbo was part of an intrinsic desire to preserve an antiquated culture and also to re-connect the essence of that antiquity with the present. Promoters of the CBCIU fully understood these concerns in such a way that a handful of its activities and programmes since inception 10 years ago are aligned towards fulfilling Ulli Beier's lifelong desires of cultural revivalism while allaying fears linked to cultural stagnation. Incidentally, members of the CBCIU BoT include two of the only three surviving members of the 1964 Osogbo Art Movement, Jimoh Buraimoh and Muraina Oyelami. Their membership owes largely to their vast experience in Yoruba contemporary visual arts which they pioneered, and most especially because their individual talents were moulded in the frame of what Ulli Beier often stood for - cultural renewal, preservation and continuity.

Further recognising the need to re-connect with the past, the CBCIU has consistently undertaken the task of immortalising the legacies of notable figures with whom Ulli Beier once shared cherished moments. In March 2018, for instance, the CBCIU invited the artistic world to celebrate the $40^{\text {th }}$ anniversary of the death of Duro Ladipo. One of the major highlights of the week-long event was a National Colloquium that reflected on the enduring theatrical legacies of the late playwright and the CBCIU's quest to build a mausoleum and rehabilitate the defunct Mbari Mbayo Club in Osogbo in Duro's honour. ${ }^{28}$ A robust partnership between the Duro Ladipo family and the CBCIU has since commenced as part of the latter's resolve to memorialise and at the same time resuscitate the thespian's artistic legacies. An award prize was also instituted beginning from 2018, for winners of the Annual Duro Ladipo Memorial Inter School Theatre Competition.

Sponsored by the CBCIU, this competition, which targets theatre clubs in select secondary schools in Osogbo, is aimed at encouraging individual and group interests in Yoruba stage plays, and also imprints in the minds of these young students the pioneering contribution of Duro in Nigeria's theatrical performances. ${ }^{29}$

In late 2016, the CBCIU, in collaboration with the 'Knowing Each Other' project based at the University of Birmingham, United Kingdom, and Osun State University, Osogbo, Nigeria, organised a one-day workshop/town and gown meeting on 'Religious Identity and Inter-faith Relations in Southwest Nigeria'. The occasion opened up spaces for a meaningful interactive exchange with religious stakeholders, traditional rulers, academics and the general public, and as well encouraged a fact-based inter-faith debate. ${ }^{30}$ Furthermore, it

\footnotetext{
Language (12-15 December 2012); facilitated artist-in-residence visits for many artists at the CBCIU, among others.

${ }^{28}$ Femi Makinde, 'CBCIU to Turn Duro Ladipo's Grave to Tourist Centre', Punch, 19 March 2018.

${ }^{29}$ Personal communication, Mrs Sholabomi Duro-Ladipo Akinsola, CBCIU, 23 March 2019.

${ }^{30}$ Religious Identity and Inter-faith Relations in Southwest Nigeria,

http://www.centreforblackculture.org/events/religious-identity.php, accessed 22 March 2019.
} 
highlighted the importance of the CBCIU as a facilitator of intercultural and inter-religious exchange in Osogbo. This collaborative effort most importantly underscores one of the cardinal objectives of the CBCIU which is to 'give greater recognition ... to intellectual dialogue [and] its interreligious component in order to reinforce social cohesion in Nigeria's pluralistic society and beyond'. 31

Also in August 2010, the CBCIU, with the support of UNESCO, the Federal Government of Nigeria and Osun State government (Nigeria), organised the 'First Global Conference of Black Nationalities, in Osogbo, Nigeria'. Themed 'The Past, the Present and the Future of a Rich Heritage', the conference was a clarion call and invitation to 'the global vanguard of culture to "come back home" to re-examine the past, evaluate the present and strategically look into the future of a rich heritage - the black heritage'. ${ }^{32}$ Although organised to commemorate the abolition of slavery, the conference was particularly designed to call global attention to the significant contributions made by African slaves and their descendants to the development of their new localities and the world at large. ${ }^{33}$

These programmes among several others are informed by a number of immediate factors, including to promote inter-religious and cultural dialogues, facilitate knowledge-sharing and uphold diversity, tolerance and pluralism ${ }^{34}$ - all enduring activities for which Ulli Beier lived and died. The CBCIU, therefore, stands for two closely related purposes: one, its rich Archives which are a reminder of a very interesting past; and two, its programmes which reinforce this inherited material legacy in a way that continually seeks cultural relevance and perpetuity.

\section{THE ULLI BEIER ARCHIVES AND SUMMARY OF HOLDINGS}

The Ulli Beier Archives or collection is housed in the Archive and Documentation Room/ Unit of the CBCIU Administrative Block. The Archives are open to the general public on weekdays between 9:00 am and 3:00 pm but not on weekends or on national and state holidays. Visitors are required to sign the CBCIU Visitors' Register, stating their aims for using the Archives or to simply make a brief remark or comment. ${ }^{35}$ There are between 500 and 800 official and unofficial visits to the CBCIU annually. Although these are conservative estimates, there are specific times in the year when total visits surpass the above estimates. ${ }^{36}$ For instance, in 2018 and to mid-2019, the CBCIU hosted a number of programmes that included seminars, colloquia, conferences, exhibition and cultural performances, each attracting a large number of people from all walks of life. ${ }^{37}$ Some of these visitors include students of primary, secondary and tertiary institutions within and outside the state, who come for excursions and other educational purposes, professional artists (sculptors, painters, local cloth weavers among others), academics and artists-in-residence. Others are dance and drama troupes, musical ensembles, members of the diplomatic corps, curators and renowned personalities who come on private visits. ${ }^{38}$

\footnotetext{
${ }^{31}$ Religious Identity and Inter-faith Relations.

32 Report on the First Global Conference of Black Nationalities, themed: 'The Past, the Present and the Future of a Rich Heritage' held in Osogbo, Osun State, Nigeria, 23-26 August 2010.

33 Report on the First Global Conference.

34 http://www.centreforblackculture.org/content/organisational-information.php, accessed 22 March 2019.

${ }^{35}$ The Register recorded 10 visitors in 2009, 74 in 2010, 7 in 2011, 6 in 2012, 7 in 2018 and 8 as at 29 July 2019 . It is important to state here that the total figures in the Register are not conterminous with the visits in a year as some are not duly registered for reasons that are not clear. Also, between 2013 and 2017, the CBCIU was closed over the status of ownership, foreclosing any form of visit from the public. See CBCIU Visitors' Register.

${ }^{36}$ Several copies of CBCIU programme Attendance Lists of 2018 were cited by the author and attest to these estimates.

37 Personal communication, Mr Akangbe Babatunde, CBCIU Staff, 3 April 2019.

38 Some of the visitors include: Arieud Wiel, Ambassador of Kingdom of the Netherlands in Nigeria, wife, Mathilda Van Wiel and Ronald Sonneman, Second Secretary for Political Affairs and Cooperation at the Netherlands Embassy, Abuja, Nigeria who visited the CBCIU on 28 August 2009;
} 
Pictures are not allowed to be taken, and no materials, particularly books, journals, newspapers and magazines may be photocopied or taken away. Researchers are granted permission to write down useful areas found in any material of interest but no materials can be borrowed. There are no registration fees but all users or visitors to the Archives are required to submit a letter in person to the Archives and Documentation Unit not later than three weeks before the actual visit. Adequate security is provided all year round. These requirements are expected to be adhered strictly to guarantee not only the safety of these rare collections but to ensure that they remain in excellent physical condition pending their digitisation.

What will follow here is a summary of holdings in the Archives which contain Ulli Beier's private works such as books and journals and over 700 slides and negatives of pictures taken in several parts of Yorubaland in the 1950s and early 1960s. It must be stated that what is presented below is far from an exhaustive list of the inventories contained in the Archives. There is, however, an extensive 94-page document referred to as the Hand List of Publications in the Centre for Black Culture and International Understanding, Osogbo, ${ }^{39}$ drawn up by the CBCIU archivist, ${ }^{40}$ containing an inventory of all holdings in the Archives with the names of authors, descriptions of the works, subject matter, beginning and concluding dates of each work (if available), classification marks and reference numbers. Although the Hand List proves invaluable for researchers, most of the publications on the shelves are not arranged serially as indicated in the Hand List's reference numbers, hence making a simple search challenging. Incidentally, the Hand List is not a public document and has never been admitted into the public domain. For reasons of space, I was able to organise the inventories in the 94page document into a compact (tabular) form with brief explanations for adequate comprehension, a task that is very different from its ambiguous appearance in the Hand List. The Hand List was made available to this author for research purposes and after a request to view the document in person was made, as is standard practice at the Archives. Being an exclusive document, which by the way is not properly referenced, it explains why this author made a caveat earlier in the article to show specifically that what will be identified subsequently here is not exhaustive but, indeed, a summary of the inventory.

\section{BOOKS}

I identified in the Hand List over one thousand books dating back to 1921. It would be quite difficult to list each book identified in the Hand List but, nevertheless, they contain diverse themes in the arts and humanities fields, with specific focus on the Yoruba and, to a lesser degree, on the Igbo and Western Delta peoples of the Southeast and South-South regions of Nigeria with whom Ulli Beier also had very interesting interactions and long-term relationships. There are also literatures on themes outside Nigeria.

Prof. Simon Ayeleroun Akpona, Rector de l'Université de Parakou, Republic du Benin, Benin, on 16 September 2009; Mary M. Khimulu, Ambassador and Permanent Delegate of Republic of Kenya to UNESCO Paris, on 10 March 2010; Wole Soyinka, renowned playwright visited in 2010; Yoruba Department, Kings College, Lagos, Nigeria, on 8 August 2011; Dr Shariene Khan, Rhodes University, South Africa, on 15 February 2018; Ronya Man, artistic director and acting coach based in Lagos, on 19 April 2018; Igbo Corpers Association of St. Charles Grammar School, Osogbo, on 27 June 2019; Prof. Jonathan Haynes, Long Island University, New York, USA, on 4 July 2019; and Students of Emmanuel Alayande College, Oyo, Nigeria, visited in 2018 and early 2019. See CBCIU Visitors' Register.

${ }^{39}$ Hand List of Publications in Centre for Black Culture and International Understanding, Osogbo, a document prepared by the CBCIU Archivist.

${ }^{40} \mathrm{Mr}$ Gbeola Olufemi Michael, Archivist at the CBCIU, provided the author with access to the Ulli Beier Archives. Sincere appreciation to him for providing answers to pressing and endless questions which proved invaluable for this article. 


\section{JOURNALS}

The Archives contain a record of about fourteen different journals dating back to 1940 . Most of the journals are in partial runs while others come in a single volume.

\begin{tabular}{|c|c|c|}
\hline $\mathrm{S} / \mathrm{N}$ & Journal & Publication date \\
\hline 1. & $\begin{array}{l}\text { Nigeria: A Quarterly Magazine of General } \\
\text { Interest }\end{array}$ & $1940 ; 1948-64$ \\
\hline 2. & Présence Africaine & $1948 ; 1955-63$ \\
\hline 3. & $\begin{array}{l}\text { African Affairs: Journal of the Royal } \\
\text { African Society }\end{array}$ & $1950 ; 1954$ \\
\hline 4. & The African Music Society Newsletter & 1952 \\
\hline 5. & $\begin{array}{l}\text { Odu: Journal of Yoruba and Related } \\
\text { Studies }\end{array}$ & $1955-64$ \\
\hline \multirow[t]{2}{*}{6.} & $\begin{array}{l}\text { Black Orpheus: A Journal of African and } \\
\text { Afro-American Literature }\end{array}$ & $1957-68$ \\
\hline & Nigeria Magazine & $1964-66 ; 1975-77 ; 1980 ; 1982-87$ \\
\hline 7. & $\begin{array}{l}\text { African Notes: Bulletin of the Institute of } \\
\text { African Studies, University of Ibadan }\end{array}$ & $1967 ; 1971-72 ; 1983 ; 1986-89$ \\
\hline 8. & Okike: A Nigerian Journal of New Writing & $1971-72 ; 1974 ; 1981 ; 1985$ \\
\hline 9. & Journal of Caribbean Studies & 1980 \\
\hline 10. & AFA: Journal of Creative Writing & 1982 \\
\hline 11. & Bayeuth African Studies Series & $1984 ; 1988$ \\
\hline 12. & $\begin{array}{l}\text { Uwa Ndi Igbo: Journal of Igbo Life and } \\
\text { Culture }\end{array}$ & 1984 \\
\hline 13. & $\begin{array}{l}\text { IMODOYE: A Journal of African } \\
\text { Philosophy }\end{array}$ & 1990 \\
\hline 14. & African Arts & $1999-2000$ \\
\hline
\end{tabular}

\section{PHOTO ALBUMS}

There are twenty photo albums in the Archives carefully placed in large white folders. Each album contains mainly series of pictures and a few art works. They are also arranged in separate volumes from 1 to 14 and then in volumes 16, 20,22, 26 and 29. All photographs were taken between the 1950 s and late 1990 s. It is not clear why some of the volumes are missing but is possible that this was how they were numbered originally.

\begin{tabular}{|c|c|c|c|}
\hline Vol. & Description & Subject & Date \\
\hline 1. & Oyinlola Olokuku: Every Inch a King & Yoruba Kings & $1950 \mathrm{~s}$ \\
\hline 2. & $\begin{array}{l}\text { The Timi of Ede, the Ataoja of Osogbo, } \\
\text { the Ogoga of Ikerre, the Osemawe of } \\
\text { Ondo, the Olokuku of Okuku. }\end{array}$ & Yoruba Kings & $1950 \mathrm{~s}$ \\
\hline 3. & Yoruba Children & Children & $1950 \mathrm{~s}$ \\
\hline 4. & Duro Ladipo National Theatre Part 1 & Travelling Theatre & 1979 \\
\hline 5. & $\begin{array}{l}\text { Yoruba Folk Opera: Duro Ladipo } \\
\text { National Theatre Part II }\end{array}$ & Travelling Theatre & 1965 \\
\hline 6. & E.K Ogunmola Theatre & Travelling Theatre & 1976 \\
\hline
\end{tabular}


(Cont.)

\begin{tabular}{|c|c|c|c|}
\hline Vol. & Description & Subject & Date \\
\hline 7. & $\begin{array}{l}\text { Yemi Bisiri: Brass Caster (Ilobu); Asiru } \\
\text { Olatunde: Copper and Aluminium } \\
\text { Reliefs (Osogbo); Adebisi Akanji: } \\
\text { Cement Sculptor (Osogbo) }\end{array}$ & Three Yoruba Artists & 1963 \\
\hline 8. & Yoruba Architecture and Wall Painting & $\begin{array}{l}\text { Architecture and } \\
\text { Painting }\end{array}$ & 1955 \\
\hline 9. & $\begin{array}{l}\text { Art by Patients in Lantoro Mental Home } \\
\text { in Abeokuta, 1951/1952 - Part I: } \\
\text { Titus, Ogundeji and Demuja }\end{array}$ & Art Works & 1951 \\
\hline 10. & $\begin{array}{l}\text { Art by Patients in Lantoro Mental Home } \\
\text { in Abeokuta, 1951/1952 - Part II: } \\
\text { Godwin, Abu, Gbadamosi, Raji Nze, } \\
\text { John, Peter and Oseke }\end{array}$ & Art Works & 1951 \\
\hline 11. & $\begin{array}{l}\text { Art by Patients in Lantoro Mental Home } \\
\text { in Abeokuta, 1951/52 - Part III: } \\
\text { Colour Slides }\end{array}$ & Art Works & 1951 \\
\hline 12. & Yoruba: Survival of a Culture & Yoruba Culture & - \\
\hline 13. & Yoruba Art & Yoruba Art & 1958 \\
\hline 14. & Egungun Ancestral Masks & Masquerade & 1956 \\
\hline 16. & Yoruba Poetry & Poetry & 1973 \\
\hline 20. & $\begin{array}{l}\text { "Middle Art": Other Sign Writers, Glass } \\
\text { Paintings in Benin, Glass Paintings in } \\
\text { Ikorodu, Museum of Popular Art in } \\
\text { the Palace of Osogbo, Onitsha Market } \\
\text { Literature, Ibibio Funeral } \\
\text { Monuments, Musa Yola: a Hausa } \\
\text { Mural Painter }\end{array}$ & Popular Art in Nigeria & 1966 \\
\hline 22. & $\begin{array}{l}\text { Agbor Dancers: Mbari Houses Ulli } \\
\text { Paintings }\end{array}$ & Art & 1963 \\
\hline 26. & Ibrahim el Salahi; Obiora Udechukwu & Artists & 1962 \\
\hline 29. & $\begin{array}{l}\text { Futa Helu and the Atenisi University (2) } \\
\text { The Cemetery of Nuku Alota }\end{array}$ & Tonga & 1996 \\
\hline
\end{tabular}

\section{BOX 1: LITERATURES, DOCUMENTS AND PICTURES}

This box contains twelve items that include mainly primary documents, literatures and a few illustrative pictures.

\section{Item}

Description

$\begin{array}{ll}\text { 1. } & \text { Onitsha Popular Literature } \\ \text { 2. } & \text { Odu: Journal of Yoruba and Related Studies } \\ \text { 3. } & \text { Nine Publications on Australian Aboriginals and other Yoruba } \\ \text { Cultures (Limited Edition) } \\ \text { I. } & \text { Iwalewa 1 on Iwalewa Haus on Yoruba Culture } \\ \text { 5. } & \text { Twins Seven-Seven Diaries }\end{array}$




\begin{tabular}{ll}
\hline \hline Item & \multicolumn{1}{c}{ Description } \\
\hline 6. & $\begin{array}{l}\text { Iwalewa } 3 \text { on Various Artists - Salahi, Mongongo, Sheiich Ramadan, } \\
\text { Kakutli and Soyiemez. } \\
\text { (1.) Ibibio Movements (2.) In an African University }\end{array}$ \\
7. & Iwalewa 4 on India, Papua New Guinea and Australia \\
8. & Duro Ladipo and Mbari Mbayo \\
9. & Architecture in Africa \\
10. & Yoruba People \\
11. & Olorisa \\
12. & Sango Festival + Carvings \\
\hline
\end{tabular}

\section{BOX 2: PICTURES}

In this box are twelve items containing over 370 pictures each carefully packed and tagged in categories on unrelated themes, events and traditional preoccupations.

\begin{tabular}{lll}
\hline \hline Item & \multicolumn{1}{c}{ Description } & No. of photos \\
\hline 1. & Yoruba Arts + People & 34 \\
2. & African Architecture & 33 \\
3. & African Artist & 24 \\
4. & Yoruba People (1) & 25 \\
5. & Yoruba Cement Sculpture and Architecture & 41 \\
6. & People & - \\
7. & Yoruba Children & 52 \\
8. & Duro Ladipo and Mbari Mbayo & 29 \\
9. & Architecture in Africa & 17 \\
10. & Yoruba People (2) & 30 \\
11. & Olorisa & 44 \\
12. & Sango Festival + Carvings & 50 \\
\hline
\end{tabular}

\section{PHOTOGRAPHS, SLIDES AND FRAMED PICTURED}

This repository contains very rich archival materials that include over 700 photographs with carefully preserved negatives and slides all dating back to the 1950s, 1960s and early 1970s. Over a hundred of these photographs document diverse cultural aesthetics such as Yoruba deities, carved images, traditional devotees, priests, priestesses, shrines, palaces, festivals, local artists, wood carvers, traditional worshippers, kings, important dignitaries, commoners, palace crowns, mud houses, roof tops, ritual performances, trances, theatrical events and all kinds of societal events and traditional agencies that the 1950s and 1960s in Nigeria offered. About 350 ( $3 \mathrm{ft} \times 2 \mathrm{ft}$-sized) framed pictures have been made separately from these photographs, some of which contain pictorial everyday ritual activities and traditional performances of prominent Yoruba kings of the period at the annual festivals and court sessions. Others include native Yoruba drums, pictures from the travelling theatres of the late 1950s and 1960s, beaded crowns, literary writings and other captivating historical pictures. Some of these framed pictures are openly displayed for visitors and researchers. 


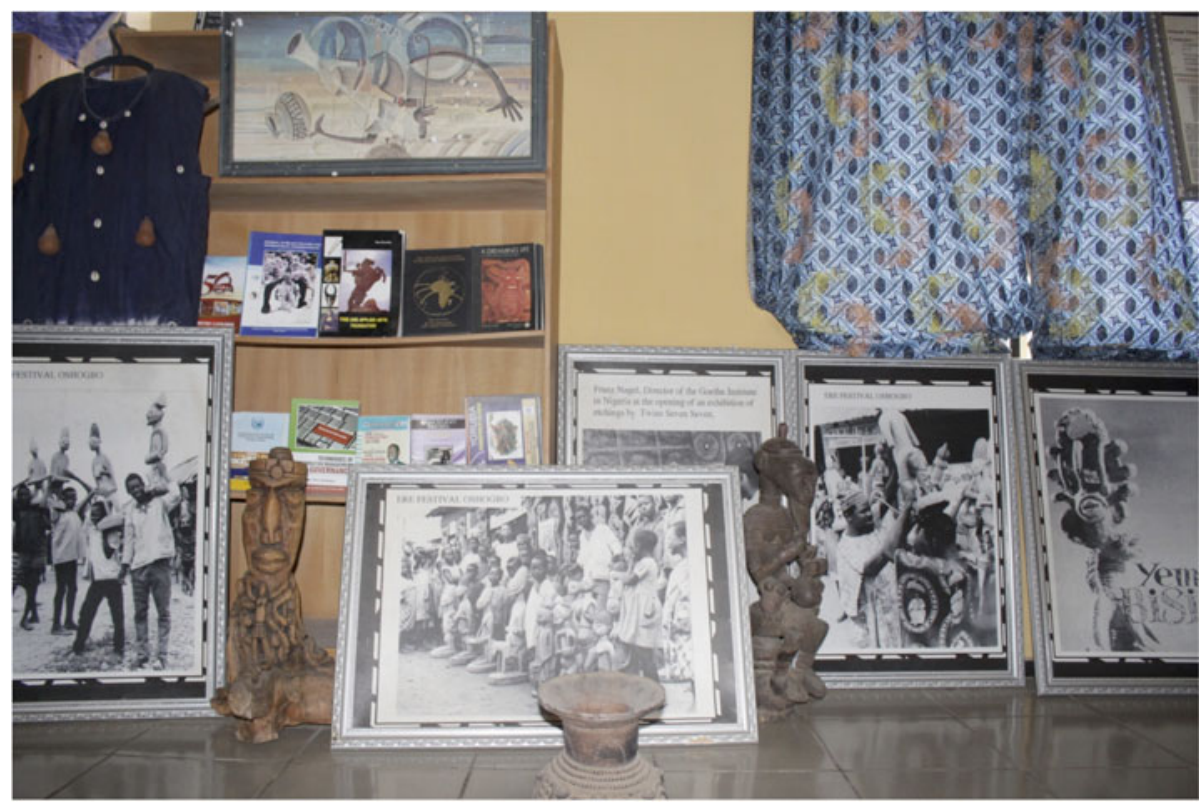

Figure 1: Framed pictures, wood carvings, hunter regalia, paintings and books as major components of the Ulli Beier Archives at the CBCIU. Photo credit: Babatunde Akangbe and Raheem Oluwafunminiyi.

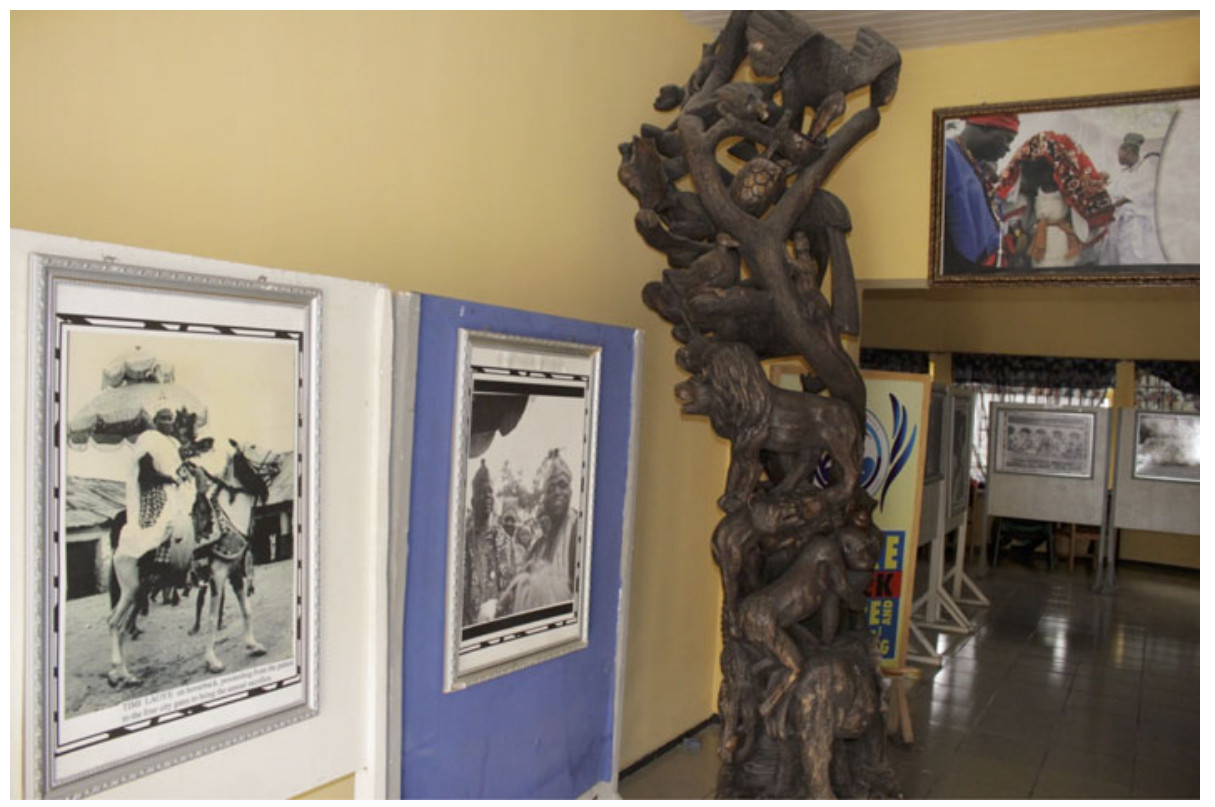

Figure 2: On the left are two framed pictures of traditional rulers - (Oba Timi John Adetoyese Laoye I (1946-75) [on horse], Oba Moses Oyinlola (1934-60) and Oba Samuel Adenle II (1944-75) - taken by Ulli Beier in the 1950s. Close to the frame is a tall wood carving called the Animal Kingdom acquired by the CBCIU from a local wood carver. To the rear is one of the temporary exhibition sections. Photo credit: Babatunde Akangbe and Raheem Oluwafunminiyi. 


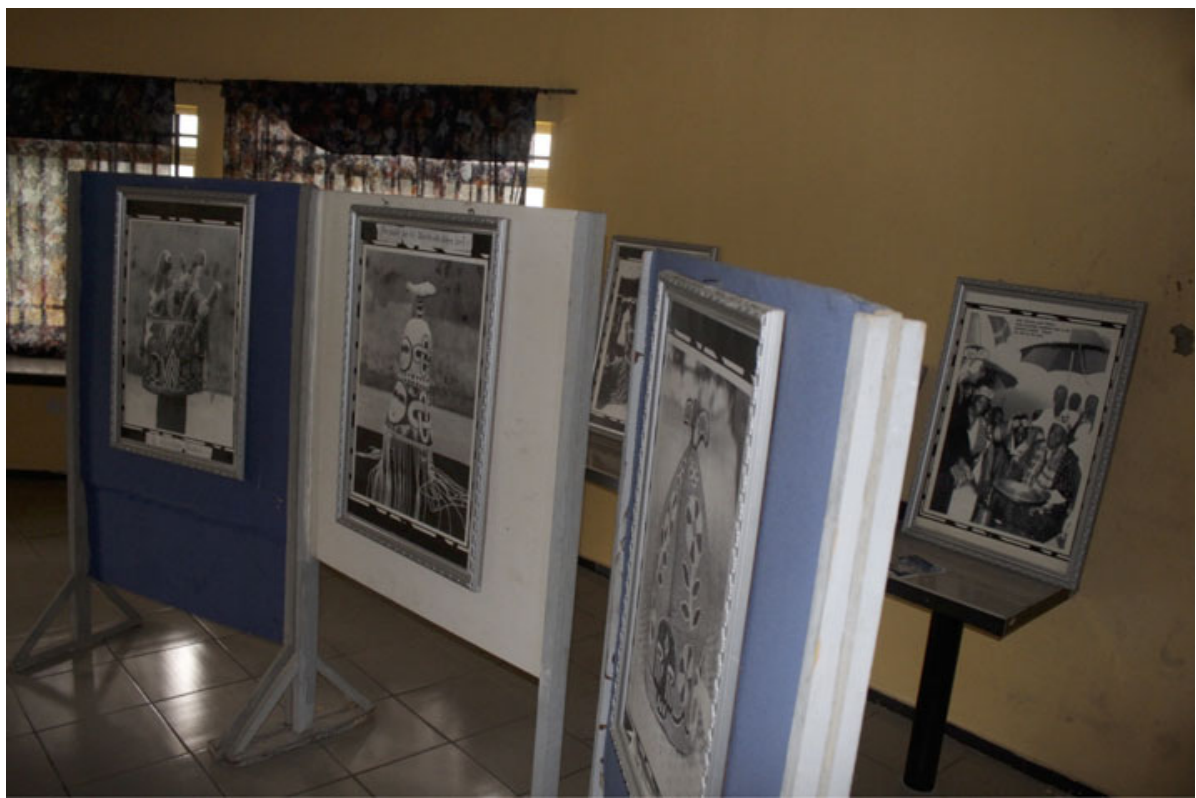

Figure 3: Framed pictures showing sacred Yoruba crowns taken in Okuku town by Ulli Beier. Photo credit: Babatunde Akangbe and Raheem Oluwafunminiyi.

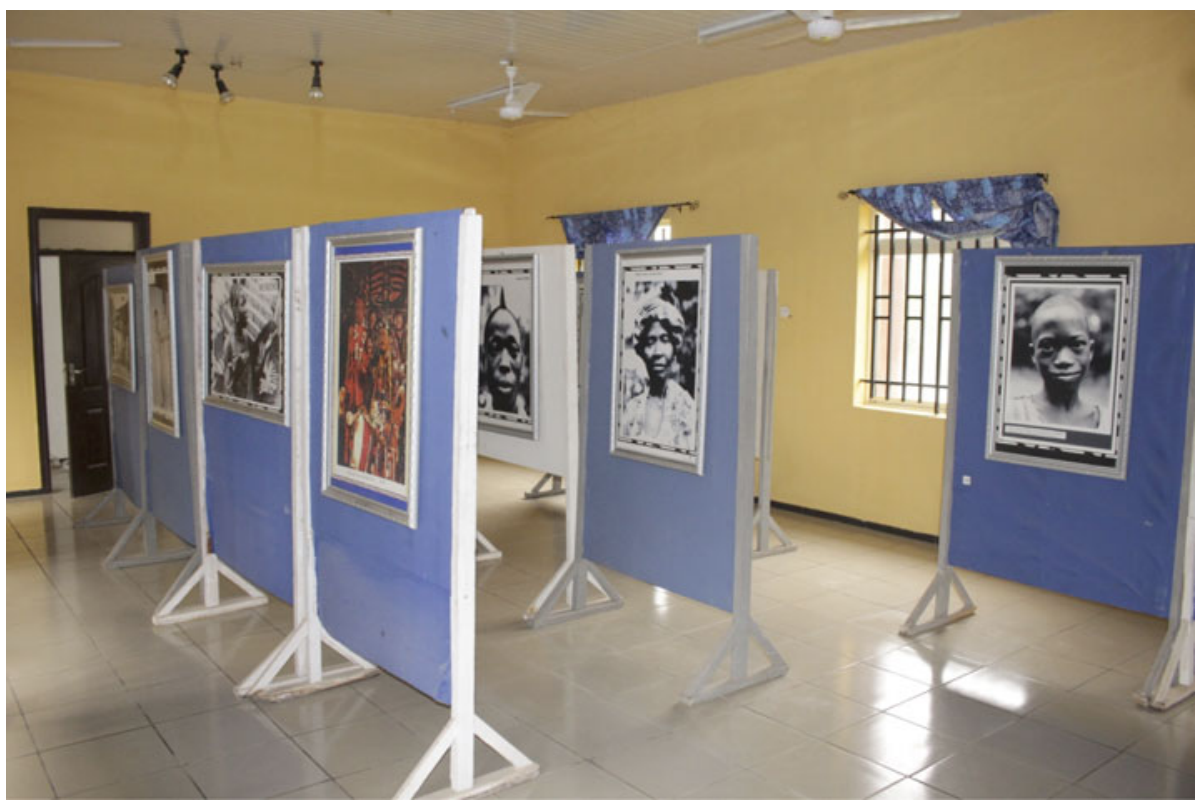

Figure 4: Framed pictures on exhibition stands mounted for visitors and users viewing. Photo credit: Babatunde Akangbe and Raheem Oluwafunminiyi. 


\section{EXHIBITION PHOTOS/POSTER DESIGNS}

There are altogether thirty poster designs, exhibitions photos/framed pictures, pottery designs, print textiles, tapestries and terracotta works. These paintings were produced and designed between 1964 and 1997 by international artists such as Georgina Beier, Adebisi Fabunmi, Twins Seven-Seven, Muraina Oyelami, Mufu Ahmed, Rotimi Togbo, Rufus Ogundele, Jimoh Buraimoh and Ademola Onibonokuta. A large number of these paintings were exhibited at such places like the Mbari Club, Ibadan and Mbari Osogbo, Nigeria; University of Ife, Nigeria; the German Cultural Institute, Nigeria; Papua New Guinea; Iwalewahaus, Germany among others.

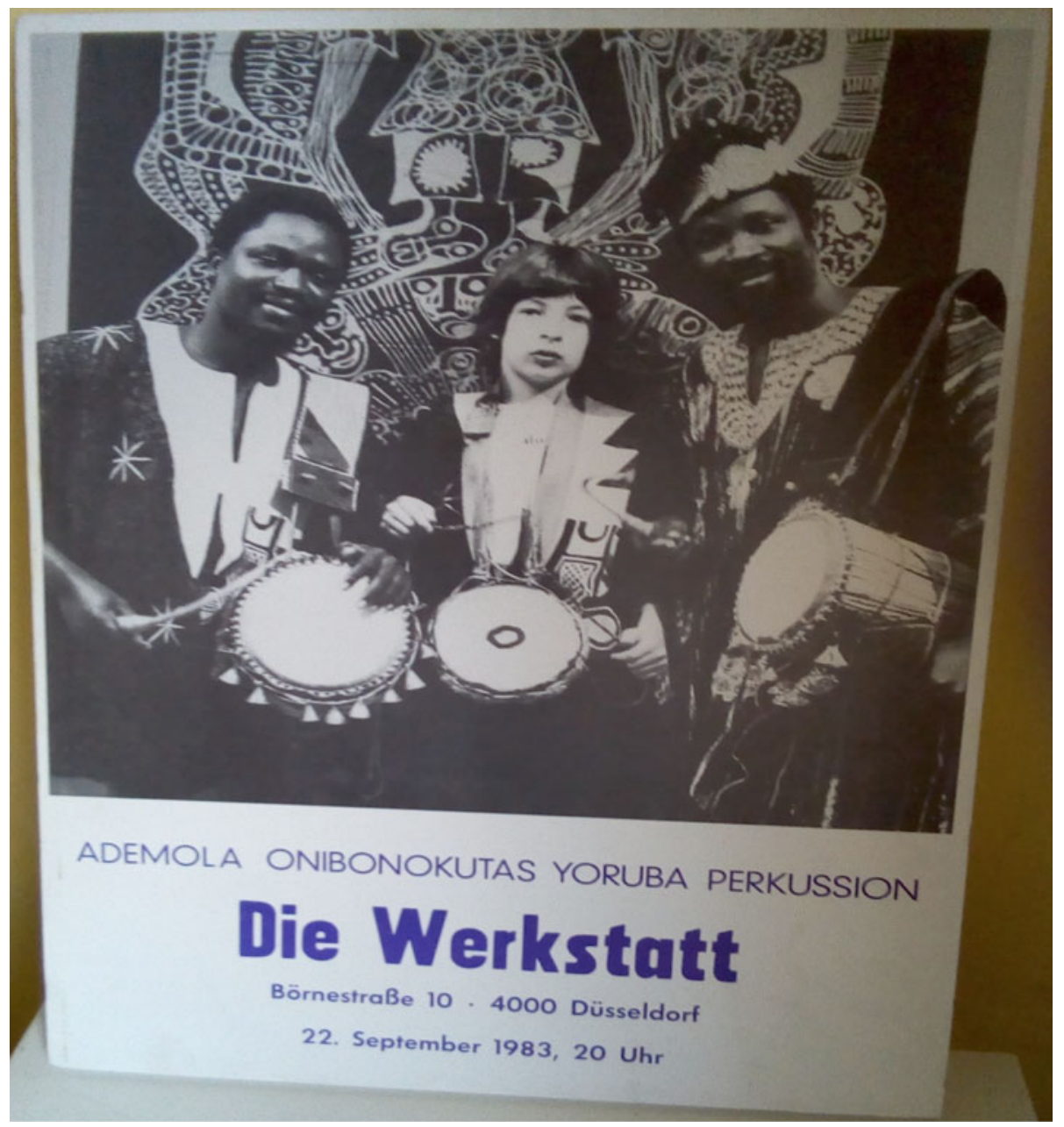

Figure 5: Framed exhibition poster introducing Ademola Onibonokutas Yoruba Percussion at Dusseldorf, Germany in 1983. Photo credit: Raheem Oluwafunminiyi. 


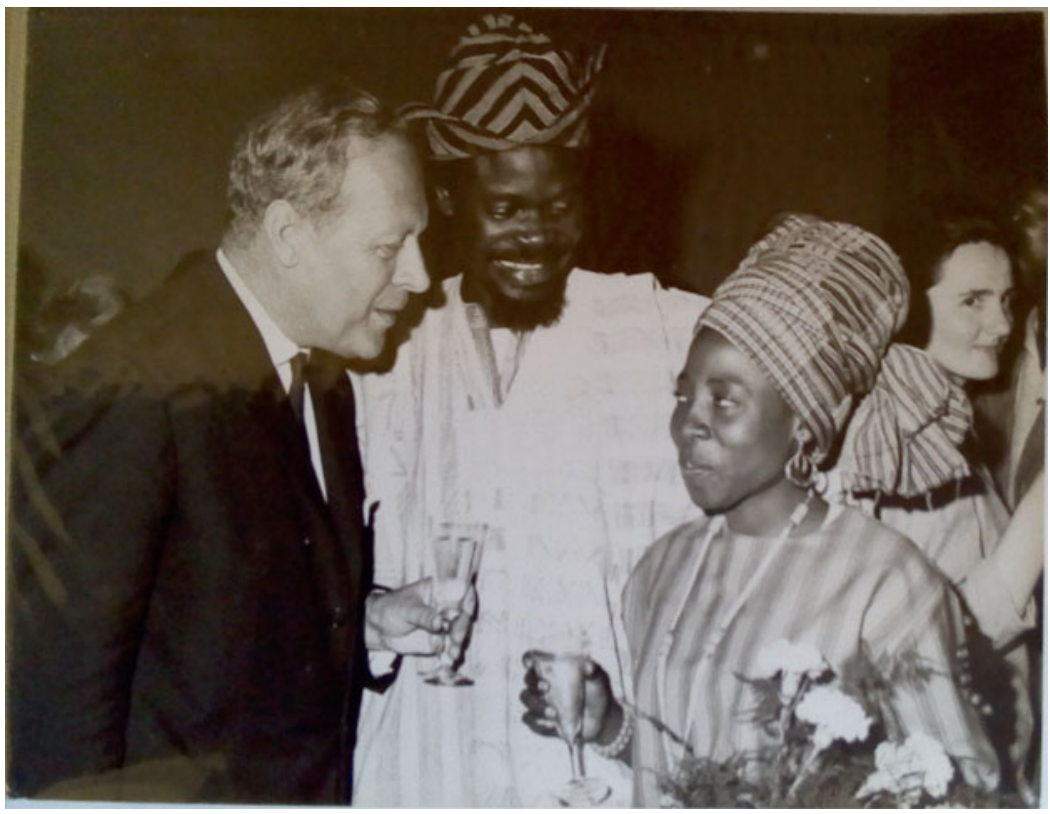

Figure 6: Duro Ladipo, Mrs Abiodun Duro Ladipo, and German Ambassador to Nigeria, Count Posadowski, in Berlin, Germany, 1964. Photo credit: Raheem Oluwafunminiyi.

\section{MISCELLANEOUS INVENTORIES}

The repository also contains several other items and materials that the CBCIU acquired to complement the Archives inherited from Ulli Beier. These materials include audio/video compact discs from commissioned works, audio-visual archival materials from the Institute of African Studies, University of Ibadan, Nigeria, wood carvings, well-preserved hunter regalia, new journals and other literary materials from research, culture and art institutes and centres in Nigeria, new book publications, paintings from renowned and upcoming painters, feasibility study reports, touring notes and other vital historical documents. Others include Duro Ladipo's Mbari Mbayo, the Osogbo building which served as the earliest theatre and studio workshops of the Osogbo Art Movement, and Duro Ladipo's costumes and props used in most of his plays. ${ }^{41}$

\section{CONCLUSION}

The CBCIU is located between the historic Yoruba towns of Ede and Osogbo. Both towns apparently played very important roles in Ulli Beier's search for cultural meanings and could invariably explain his decision to live close to 12 years - in Ede from 1951 to 1954 and in Osogbo from 1958 to 1966, immersing himself in self-edification among the local population. It was in Ede, interestingly, that Ulli Beier was inaugurated into the Yoruba worldview $^{42}$ while Osogbo served the greater purpose of his cultural flowering. One could therefore understand why Ulli chose Osogbo, more than any other Yoruba town, as the final

${ }^{41}$ http://www.centreforblackculture.org/content/situation-analysis.php, accessed 22 March 2019.

42 Siyan Oyeweso and Raheem Oluwafunminiyi, 'The Pioneering Role of Ede Town in the Ontological Development of Ulli Beier and Susanne Wenger's Yoruba Religious Thought', paper presented at the Centre for Black Culture and International Understanding Seminar Series, CBCIU Seminar Hall, Osun State, 16 May 2019. 
resting place for all his life works. In each of the Yoruba towns visited, Ulli Beier was not only deeply connected with the local people but also became an active participant in several African religious festivals, worship and ritual practices. He carefully documented vast amounts of cultural expressions, many of which at that particular period in time were fast fading away and also seemed to lack the emergent educated class's interest. He was no doubt an agent of change and contributed immensely in the elevation of cultural intangibles and tangibles through robust documentation of Yoruba praise poetry (oriki) and other categories of oral history on the verge of being lost to the old age or death of its gatekeepers. Some of the shrines he helped to rebuild with commissioned cultural ensembles in many Yoruba towns are emblematic of the concerted efforts by him and the few surviving individuals at the time to leave behind an enduring legacy. ${ }^{43}$

The Ulli Beier Archives at the CBCIU remain rich mines of information and also contain deviating forms and categories of materials that are non-uniform and uncategorised. ${ }^{44}$ While a significant numbers of these materials are tagged by their original owners (Ulli and Georgina Beier), it remains very difficult to decode their sources sometimes and how they link with the period in which they were actually developed or made. ${ }^{45}$ Although none of the materials appear to have been damaged or show signs of wear and tear, given the very strict attention and care by its promoters, there is nonetheless a need for the CBCIU to embark on 'aggressive' and full digitisation and importantly detailed cataloguing similar to the way that it is presently being pursued at Iwalewahaus, University of Bayreuth, Germany, where the other archival materials are understood to be domiciled. ${ }^{46}$

That so much remains today of what Yoruba cultural history appeared in the 1950s and 1960 s is owed to Ulli Beier's painstaking strides in documentation. It is, however, through the CBCIU's Archives that much of this could be better appreciated. And as worthy inheritors to that complex past that struggled with modernity, what the CBCIU has done is to carry on with Ulli Beier's legacies through programmes that are strictly concerned with the practical utilisation of cultural dialogues as agents of change.

43 One of such shrines is in the palace of the Olobu of Ilobu in Irepodun Local Government Area, Osun State, which was furnished by Ulli Beier during his stay in the town between 1954 and 1958. Personal communication, Abubakar Abubasit, indigene of Ilobu, 16 August 2019.

${ }^{44}$ Isabelle Malz and Nadine Siegert, The Mbari Artists and Writers Club in Ibadan, Bayreuth: Iwalewabooks, 2018.

45 Gbeola Olufemi Micheal, 'Digitising Archival Materials: A Case Study of Ulli Beier Photographic Estate, University of Bayreuth, Iwalewahaus, Germany', paper presented at the Centre for Black Culture and International Understanding Seminar Series, CBCIU Seminar Hall, Osun State, 25 May 2019.

${ }^{46}$ Memorandum of Understanding between The Centre for Black Culture and International Understanding, Osogbo, Osun State, Nigeria and The University of Bayreuth, Iwalewahaus, signed at Bayreuth, Germany, 24 July 2018. 